Горан Милорадовић Институт за савремену историју

791.222:355.426(497.1)"1941/1945" Београд

goranm065@gmail.com

https://doi.org/10.18485/ai_most.2017.ch5

\title{
ЦЕЛУЛОИДНИ МОСТ: \\ ДВЕ СУПРОТСТАВЉЕНЕ ИНТЕРПРЕТАЦИЈЕ ДРУГОГ СВЕТСКОГ РАТА У ЈУГОСЛАВИЈИ \\ НА ИГРАНОМ ФИЛМУ (1941-1991) ${ }^{1}$
}

Услед специфичне позиције Југославије између НАТО пакта и Варшавског споразума у југословенском и страном играном филму су се појавила два различита тумачења Другог светског рата у Југославији. Један дискурс афирмише вишенационалну југословенску државност и њене везе са Западом, по цену очувања комунистичке власти у њој. Други истиче српско-руске историјске везе и традиционалне вредности, систематски поткопавајући службена југословенска тумачења најновије историје и постепено се ослобађајући идеолошких илузија.

Кључне речи: ратни играни филм, Југославија, НАТО пакт, Варшавски споразум, комунистичка идеологија, југословенство, четници, партизани, нацисти.

Социјалистичка Југославија је, услед промена у међународној политичкој арени, била принуђена да лавира између два војнополитичка блока: НАТО и Варшавског

1 Чланак је резултат рада на пројекту: Срӣско gрушитво у јуїосло-

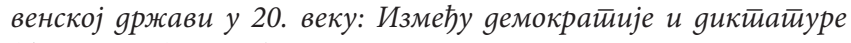
(бр. 177016 ), који финансира Министарство просвете, науке и технолошког развоја Републике Србије. 
пакта. Промене политичког курса су се, у одређеној мери, одражавале и на њену културну продукцију, посебно на филм. Овај чланак се заснива на претпоставци да се анализом идеолошких и политичких садржаја филма могу извести одређени закључци и о спољној и унутрашњој политици Југославије. Начини представљања осетљивих тема у кинематографији, попут оних у вези са тумачењем Другог светског рата у Југославији или сукоба са Совјетским Савезом 1948. године, омогућују да се филм користи као историјски извор за политичке и друштвене теме. Може се претпоставити да су информације које се на такав начин прикупе поуздане, јер је филм био пажљиво контролисан од стране партијске државе. Оно што је стизало на биоскопски и телевизијски репертоар не само да је имало „имприматур“ политичке и идеолошке исправности - било је често и директна порука јавности. Уколико би био снимљен филм који је на неки начин био у супротности са спољном политиком Југославије, он је уклањан са репертоара. То је изазивало скандале локалних, а понекад и међународних размера. Филмови чије приказивање је било забрањено такође се могу сматрати поузданим извором, али са другачијим политичким значењем. Управо забрана доказује значај поруке коју они носе. Трећи индикатор су међународне филмске копродукције, јер у контексту Хладног рата сваки такав подухват имао је и неко политичко значење. Три наведена аспекта одређују историографски значај тих филмова (Милорадовић 2012 : 258-280, 341-345, 355-365).

Политички ангажован филм о Југославији појавио се још током Другог светског рата. Тада су државе које су током Хладног рата чиниле супротстављене блокове биле савезнице са окупираном Југославијом и настојале да збивања у тој земљи искористе у пропагандне сврхе. Основни материјал за филмску обраду произлазио је из чињенице да се крајем пролећа 1941. године у Југославији 
јавио герилски отпор окупаторима, тако да исте године почиње и производња играних филмова који публику упознају са тим збивањима. Управо ту почињу две различите, али континуиране нити филмског представљања југословенске стварности, које су понекад текле паралелно, а понекад се укрштале, да би се на крају посматраног периода потпуно разишле. Материјал коришћен у овој анализи захвата распон од пола века, односно време између две велике промене у историји Совјетског Савеза и Југославије: од напада сила Осовине на те две државе 1941. године, до њиховог нестанка са политичке мапе Европе 1991. године.

Два супротстављена друштвена система и војнополитичка блока давала су тон амбијенту у коме је настао највећи број анализираних филмова: НАТО пакт (формиран 1949. године) и Варшавски споразум (основан 1955. године). С обзиром да се Југославија налазила на линији додира та два савеза, логично је да су се они борили за дефинисање и јачање свог утицаја у њој. С друге стране, и југословенска кинематографија је, на свој начин, представљала међународну позицију државе у којој је настајала. Те чињенице условиле су високу политизованост и идеологизованост кинематографије, а нарочито играног филма као најважнијег дела биоскопског репертоара. У овом чланку пажња је усмерена на три групе филмских тема у којима је идеолошки и политички садржај био посебно изражен, а које се међу собом донекле преклапају и додирују: 1) Други светски рат у Југославији представљен у страним филмовима и копродукцијама; 2) представљање револуција и грађанских ратова на југословенском и копродукционом филму; 3) раскол између Југославије и других социјалистичких држава 1948. године представљен на југословенском филму.

Први филм тематски везан за Југославију настао је у Совјетском Савезу током Другог светског рата, са циљем да грађане психолошки мобилише и припреми за ратне напоре и жртве. То је средњометражни совјетски 
филм снимљен августа 1941. године, под називом Сӣo за јеgноі (Сто за оgного), у режији Герберта Рапапорта и продукцији Ленфиљма. ${ }^{2}$ Ради се о стрељању талаца, за које се јасно каже да су Срби, а зову се Данило, Никола, Јанко, Милош (Kosanović, Tucaković 1998: 103). Потом је у СССР-у настао још један средњометражни играни филм Ноћ наg Беоіраgом (Ночь над Белградом), режисера Леонида Лукова, снимљен септембра 1941. године у Ташкентском киностудију. ${ }^{3}$ Фабула је посвећена отпору који илегалци и грађани пружају Немцима у окупираном Београду на почетку рата, а сврха филма је подизање морала совјетских грађана. Иако је филм идеолошки изразито неутралан, гледаоцу се јасно ставља до знања национална припадност ликова, односно да се Немцима супротстављају Срби. При крају филма може се видети особа која се, наглашено, крсти на православни начин. То је позивање на старе српско-руске и православне везе и сентименте. Окупатори су представљени карикатурално, као приглупе, бахате и прождрљиве силеџије, које понижавају окупирано становништво и изазивају оправдани револт. У наведена два филма из 1941. године нема идеолошких обележја или теза, апелује се на словенску солидарност и патриотизам.

Две године касније, западни савезници су довршили снимање два филма о романтичној герили на Балкану за америчку и британски публику. Тематски, они су међусобно слични и имају чак и врло сличан наслов, што сугерише да је, бар у почетку, постојала сагласност око њиховог садржаја. Најпре је снимљен амерички филм Чейници! Борбена іерила (Chetniks! The fighting guerrillas), у режији Луиса Кинга (Louis King) и продукцији $20^{\text {th }}$

Филм је епизода у оквиру кинематографске едиције Боевой киносборник № 2.

3 Филм је епизода у оквиру кинематографске едиције Боевой киносборник № 8. 
Century Fox (Savich 2017b). Филм је премијерно приказан 11. јануара 1943. године. Радњу чини преплитање породичне драме главног јунака пуковника Драже Михаиловића, који је представљен као частан и способан официр који предводи борбене акције својих војника, представљених као патриоте. На почетку филма види се грб Краљевине Југославије и више пута помиње назив те државе, а официри носе регуларне униформе краљевске војске. Иако се у филму помињу Срби и Црногорци и градови Београд, Ниш и Котор, тежиште вербалних референци је на Југославији и Југословенима. Ликови Немаца су представљени сведено, као прождрљивци и глупани, али без хумора, кога у руском филму има. Сврха Кинговог филма је подизање морала и борбеног расположења у Сједињеним Државама.

Исте 1943. године у Великој Британији је снимљен филм Илеїалии (Undercover), у режији руског емигранта Сергеја Нолбандова и у продукцији Ealing Studios из Лондона. Сарадник на сценарију био је др Милош Секулић, курир кога је Дража Михаиловић послао из Југославије у Лондон да успостави везу са избеглом југословенском владом и извести је о стању у земљи (Tomasevich 1975: 136). То је романтични филм о српској герили, у чијем средишту је породична прича, као и у филму Chetniks! Часопис The British Picture Post je 10. октобра 1942. године тај филм, под називом Chetnik, најавио чланком „How Yugoslavia Fights Back“, у коме се помињу југословенска герила и генерал Михаиловић (Savich 2017a). Када је 27. јула 1943. године филм дефинитивно завршен, његов првобитни назив је промењен у Undercover, док су све директне референце на четнике или Србе - уклоњене (Dick 1996 : 164). Тако је филм, после процеса преправке, испричао причу о идеолошки неутралној романтичној герили, чији главни јунаци се зову Милош и Ана Петровић. Ипак, није све могло бити промењено, па глумци 
носе препознатљиве униформе Југословенске краљевске војске, српску сељачку ношњу и шубаре са кокардама, а у једној сцени се види и православни свештеник. Сврха филма је да подстакне антинемачко расположење и укаже на постојање гериле на Балкану. Филм је био прерађен јер су Британци током 1943. године одлучили да подрже национално мешовите југословенске комунисте - партизане Јосипа Броза Тита, уместо српских монархиста - четника Драже Михаиловића. Исти филм је 1944. године, у продукцији Columbia Pictures, био поново издат за америчко тржиште, под насловом Поgземна іерила (Underground guerrillas) (Savich 2017a).

Односи СССР-а и Југославије током првих послератних година одражавају се кроз два филма, који представљају два различита политичка и идеолошка погледа на међусобне односе тих двеју држава. Први је настао совјетски филм У йланинама Јуїославије (В іорах Юі̄оставии) $)^{4}$ у режији Абрама Рома, који је довршен 1946. године у продукцији Мосфиљма (Volk 1966: 280-281; Denić 1986: 28-35). Основне идеје тог филма су, базично, поновљене поруке из филма Ноћ наg Беоїраgом: братство по оружју, словенска солидарност и заједнички непријатељ. Филм је започет као копродукција, па је и екипа за његово снимање била мешовита, совјетско-југословенска, где су Југословени учили филмски занат од совјетских колега. Снимало се током 1945. и 1946. године на локацијама у Југославији, уз обилну подршку партије и државе. Сценарио Георги Мдиванија садржи неколико политички важних теза: 1) одлуку о устанку против окупатора Комунистичка партија Југославије (КПЈ) донела је када је Трећи Рајх напао СССР, 22. јуна 1941. године; 2) главну снагу партизанског покрета чинили су Срби сељаци; 3) слобода је извојевана уз помоћ Црвене

Филм је првобитно требало да се зове Бура наg Балканом. 
армије, чији војници су сахрањени у Југославији; 4) победа је прослављена у Београду, са сликама Стаљина и Тита и совјетским и југословенским заставама. Иако се на почетку и при крају филма ритуално набрајају југословенски народи, главна радња се дешава у српској православној средини у Босни и у Београду, главни јунак се зове Славко Бабић, а његова жена Милица. Четници и њихов вођа Дража Михаиловић представљени су као сарадници Немаца, али им није дато много простора. Анте Павелић је епизодни лик. У одсудном тренутку битке помоћ партизанима пружају два црвеноармејца побегла из немачког логора. Југословенско руководство није било задовољно таквим садржајем, па је одбило да филм сматра својом копродукцијом и он је убрзо нестао са репертоара. ${ }^{5}$

Глумац Вјекослав Афрић, члан Ромове екипе, још у току снимања писао је сценарио за нови филм, заснован на битно другачијим тезама, а који ће бити искључиво домаћи производ (Ostojić 1977: 63-64; Čolić I 1984: 170171). Тако је почео рад на филму Славица, у режији Вјекослава Афрића, који је завршен 1947. године у продукцији београдског Авала-филма (Škrabalo 1998: 159-161). Основне тезе Ромовог филма добиле су дијаметрално супротне одговоре: 1) КПЈ се у рат укључила због напада на Југославију и социјалне неправде; 2) партизани су били пре свега радници; 3) у ослобађању од окупатора не учествује Црвена армија; 4) победа се прославља у Сплиту, где се види само Титова слика, хрватске и југословенске заставе. Радња филма се дешава у Далмацији, која је претежно хрватска и католичка средина, иако се на тим чињеницама не инсистира. Тако драстично размимоилажење са совјетским филмом при тумачењу тек завршеног

5 Иако је назив Државног филмског предузећа изостављен, у Југословенској кинотеци у Београду постоји копија филма направљена за југословенско тржиште, са шпицом и натписима на српском језику и латиници. 
рата није могло бити ствар личног доживљаја и слободе уметника, него одређена политика. Та политика се током 1947. године постепено одвајала од курса совјетске са којом је до тада била у пуном сагласју. Почела је борба око интерпретације недавне прошлости, а главно питање је било ко је и уз чију помоћ савладао силе Осовине. Већ наредне, 1948. године, дошло је до отвореног сукоба двеју партија и држава, који је оставио јасан траг и на филму.

Нови контекст је, поред осталог, утицао и на однос Југославије према актуелним спољнополитичким темама. То се испољило и на примеру филма Мајка Кашична, режисера Николе Поповића, снимљеном 1949. године у продукцији Авала филма из Београда, који је био уклоњен из јавности од 1949. до 1998. године. Тај филм није био званично забрањен, него је проглашен „недовршеним“. У питању је акциони филм о грађанском рату у Грчкој 1946-1949. године. Политички спорна била је оштра критика Велике Британије и Сједињених Држава у околностима када је почињао сукоб са СССР-ом; проблем је била и врло позитивна слика Совјета у време када је дошло до преокрета спољне политике и када се очекивала подршка Британаца и Американаца; најзад, била је спорна и недвосмислена подршка комунистима у грађанском рату у Грчкој у време када је већ очекиван њихов пораз. Уклањање тог филма из јавности било је последица и индикатор промене међународног положаја Југославије, због чега је његово постојање било порицано пуних пола века (Ристовић 2010: 7-21).

Дубина расцепа међу социјалистичким државама због Информбироа (ИБ) види се из кратког играног филма Тајна gвориа И.Б., снимљеног 1951. године у режији Милана Катића и у продукцији загребачког Јадран филма. У том филму нема дијалога, а фамозна Резолуција И.Б, којом је шест источноевропских комунистичких партија осудило руководство КПЈ (тј. „фаши- 
стичку клику Тито-Ранковић“) персонификује утвара, коју је алхемијским поступком призвало шест бизарно одевених гостију у једном дворцу. То је тада била више него јасна алузија на саветовања Коминформа 1948. и 1949. године на којима је двема оштрим резолуцијама била осуђена политика Југословенске партије (Адибеков 1998: 455-461, 629-660). Филм је уклоњен из јавности скоро без трага, јер је представљао преоштру сатиру у време када је сукоб око Информбироа ушао у критичну фазу. У јесен 1951. године на Далеком истоку је буктао Корејски рат, а НАТО-пакт је са Југословенском ратном морнарицом одржавао маневре у Јадранском мору, па је малициозни хумор тог филма био више него непотребна провокација Совјета.

У таквим околностима Југославија се определила за даље приближавање Западу, што је оставило трага и у филмској делатности. С једне стране, југословенски филмски цензори наједном су постали пуни разумевања за демократске и либералне вредности и западњачку естетику, па су приликом увоза филмова из САД и Западне Европе знатно ублажили своје критеријуме (Милорадовић 2012: 276). С друге стране, и филмска производња је кренула у истом правцу, што се нарочито одразило у филмовима који су рађени у копродукцији са иностраним партнерима. Није претерано рећи да је средином 1950-их година Југославија ужурбано градила својеврсни филмски „мост“ ка НАТО пакту. Тај радикални заокрет је изазвао реакције на разним странама: и код југословенске филмске публике, и код међународне филмске јавности, и на политичком плану. Тиме су се, истовремено, показале и границе кретања ка Западу, што је главни разлог да филмова таквог усмерења није било и више.

Први и најважнији у том новом низу је филм Послеgюи мости (Die letzte Brücke) из 1954. године, аустријског режисера Хелмута Којтнера (Helmut Käutner), настао 
у продукцији Удружења филмских уметника Србије (УФУС) из Београда и Cosmopol film-a из Беча. Главни филмски ликови су припадници немачких опупационих трупа, који су тада, по први пут у југословенском филму, представљени као људска бића са емоцијама, способна да мењају своје понашање. Нова, знатно блажа слика Немаца у рату у Југославији, изазвала је револт домаће публике и критике, навикнуте на нешто сасвим другачије (Čolić II 1984: 352-354; Raspor 1988: 38, 40, 41). У периоду 1947-1955. година југословенски филмови на теме из Другог светског рата чинили су $35,71 \%$ укупне домаће производње и у њима су нацисти били представљени као више или мање бруталне убице (Милорадовић 2012: 366). У том филму по први пут се види нова подела на позитивне и негативне ликове: немачка лекарка Хелга је позитивни лик, заједно са југословенским партизанима и цивилима. Усред беспоштедног рата, она је била носилац идеје хуманости и спремности на лично жртвовање из етичких разлога. Иако је филм у Југославији изазвао негативне реакције, на Канском фестивалу Марија Шел је добила прву награду за главну женску улогу (Škrabalo 1998: 212). Према италијанском критичару и теоретичару филма Луиђију Кјаринију (Luigi Chiarini), Послеgюи

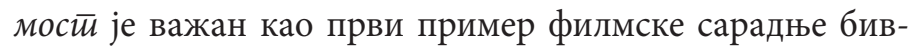
ших непријатеља после Другог светског рата, па је зато том делу посветио цело поглавље своје књиге (Delibašić 2015: 117). Ако се има у виду да је 1953. године Југославија склопила Балкански пакт са Грчком и Турском, две чланице НАТО-пакта, онда је логична потреба да се тежи ублажавању психолошке дистанце према бившим непријатељима, а пре свега према Немцима.

Међутим, ти први ефекти покушаја да се у Југославији поправи слика улоге нациста у рату на Балкану и, истовремено, побољша слика социјалистичке Југославије на Западу, убрзо су анулирани. Наредне, 1955. године, 
снимљен је филм Крвави йуй (Blodveien), у режији Коре Бергстрома (Bergstrøm Kåre) и Радоша Новаковића, а у продукцији Авала-филма и Норск-филма из Осла. То је прича о заробљеним југословенским партизанима, Србима, у немачком логору у Норвешкој. Изражена је оштра подела на позитивне ликове логораша и Норвежана цивила који им помажу у бекству и негативне ликове Немаца и норвешких квислинга који их чувају и прогоне. На фестивалу у Кану 1955. године, на протест немачке владе, забрањена је пројекција тог филма јер „вређа осећања Немаца“. Немачка делегација у Кану је рекла да филм „брука част Вермахта“. Француска је показала разумевања за немачке захтеве, јер су две државе до тада своје међусобне односе већ биле поставиле на нове основе - 1951. године је формирана Европска заједница за угаљ и челик, која је постала основа Европске Уније (Милорадовић 2012: 359).

Трећи филм, који још јасније од претходна два саопштава да се Југославија налази под америчким војним и политичким „кишобраном“, јесте Долина мира (енглески наслов: Mr. Jim - American Soldier, and Gentleman), из 1956. године, у режији Франце Штиглица и у продукцији Триглав-филма из Љубљане. Амерички глумац Џон Кицмилер (John Kitzmiller) добио је на фестивалу у Кану прву награду за главну мушку улогу. И у том филму је интересантна подела на позитивне и негативне филмске јунаке. Позитивни су ликови двоје деце - Немице Лоти и Словенца Марка, као и ликови америчких пилота и југословенских партизана. Негативни јунаци су немачки војници. У филму су два америчка авијатичара сахрањена у Југославији, тачније у Словенији, чиме се подсећају гледаоци да су и они гинули за ослобођење Југославије. Стиче се утисак да је сценариста Иван Спинчич тиме директно одговарао на садржај совјетског филма У йланинама Јуїоставије и, на неки 
начин, објашњавао и правдао нову позицију своје земље. Та три филма чинила су тематску целину усклађену са променом спољне политике Југославије. ${ }^{6}$

После Стаљинове смрти 1953. године отпочело је побољшавање совјетско-југословенских односа: совјетска делегација је 1955. године посетила Југославију, а југословенска 1956. Совјетски Савез. Том приликом договорено је и заједничко снимање једног играног филма. Први проблем је био пронаћи обострано прихватљиву тему. Предлог извесног г. Жукова Никити Хрушчову да се снима копродукција о немачком десанту на Дрвар 1944. године није био прихваћен (Милорадовић 2012: 189). Вероватно око тумачења збивања у Другом светском рату још није било сагласја, јер би се морало отворити питање односа војних представника Совјета, Британаца и Американаца који су тада боравили при Врховном штабу југословенских партизана. Осим тога, после десанта Тито је био евакуисан на Вис, под заштиту британске војске. Тај клизави терен је избегнут тако што је одлучено да тема филма буду догађаји из времена Октобарске револуције и грађанског рата у Русији, када још није било политичких и идеолошких спорова између две партије. Тако је 1958. године довршен филм Алекса Дундић (Олеко Дундич), у режији Леонида Лукова и копродукцији студија „Максим Горки“ (Киностудия им. М. Горького) из Москве и Авала-филма. Одабиром биографије хероја Октобарске револуције Алексе Дундића омогућен је симболички повратак заједничкој идеолошкој основи и искључен каснији политички спор. У филму се може видети српска застава и портрет краља Петра I, добровољци се неколико пута декла-

6 Тих година су у сарадњи са Западом снимљене и три драме, које нису имале политичког одјека: Кућа на обали, (J. A. film Kompanie из Хамбурга и Босна филм из Сарајева), Грех, (Saphir film G.M.B.Н. из Минхена и Триглав филм из Љубљане) и Два зрна іррожђ (Nikos Skulidis \& Co. из Атине и УФУС из Београда). 
ришу као Срби и православци. Црвени Дундић прети свом сународнику Павлу Хоџићу, који је на страни белих: „Гонићу те до Србије!“ - иако је 1919. година и формирана је Краљевина CXC! Тај филм се бави темом која је представљена као само руска и српска ствар - нема сложених међудржавних и међунационалних односа, иако их је било у реалности. Обе државе су ангажовале истакнуте глумце, знатна финансијска средства и помоћ двеју армија за масовне сцене. Али, већ 1957. године партијски и државни односи Југославије и СССР-а почињу да тону, а Хрушчов Југославију отворено назива „тројански коњ империјализма“" (Miloradović 2011: 91-108). Услед новог погоршања односа, премијере у СССР-у и Југославији прошле су упадљиво хладно, као непријатне формалности које су обе стране настојале да брзо обаве и још брже забораве (Милорадовић 2012: 189).

После политичког раскола који се испољио кроз филмове У йланинама Јуїоставије и Славица није било лако наћи заједнички језик за тумачења недавне прошлости. Сагласје се може видети у филму Проверено нема мина (Проверено - мин нет) из 1965. године, у режији Јурија Лисенка и Здравка Велимировића, а у копродукцији Киностудија „А.П.Довженко“ из Кијева и Ловћен-филма са Цетиња. Радња се одвија у време ослобођења Београда октобра 1944. године. Мала јединица састављена од југословенских партизана и црвеноармејаца послата је у борбу против немачких командоса који су се крили у београдској канализацији и одатле вршили диверзије и атентате. Сценарио је написан према истинитим догађајима, који су дуго били непознати широј јавности (Jovićević s.a.). Од позитивних јунака нико није преживео, али су и сви Немци уништени. Сценарио не садржи идеолошке и политичке контроверзе; акцент је стављен на карактер и личне односе јунака; прича је сведена на једну епизоду о заједничкој борби, солидарности и пожртвованости; 
тема филма се дешава у Београду; нема западњака нити јасног декларисања других југословенских националности, иако се могу чути црногорски и далматински говор и помен Каштела Старог. Међутим, најстарији међу позитивним ликовима је учесник одбране Београда из 1915. године, који каже партизанском командиру: „Ми нисмо били гори војници од вас. То да знаш!“ Пред кулминацију радње он наводи део чувеног говора свог некадашњег команданта, мајора Гавриловића: „Војници! Јунаци! Врховна команда избрисала је наш пук из бројног стања. Наш пук је жртвован за част Београда и Отаџбине. Ви, дакле, немате шта да бринете за животе ваше, они више не постоје!“'У поређењу са Славицом или Долином мира филм Проверено нема мина је потпуно српска и руска ствар - упркос владајућој идеологији.

Проверено нема мина превазилази главне проблеме интерпретације рата који су се испољили у првим играним филмовима и поново отвара могућност филмске обраде совјетско-југословенских односа на тај начин што у њихово средиште ставља - српско-руске односе. Поред тога, тим филмом је омогућен нови важан корак. Сукоб око Информбироа, који је имао далекосежне последице, у југословенској кинематографији је током 20 година био потпуно игнорисана тема, (тј. неформално забрањен), али после Проверено нема мина уследио је први талас „откривања“ Голог отока и других елемената Титове мреже логора и затвора. Најпре су се појавила три филма српских аутора и продуцената: Буђење йацова у режији Живојина Павловића и у продукцији Филмске радне заједнице (ФРЗ) из Београда, јануара 1967; затим Поgне, у режији Младомира Пурише Ђорђевића, у про-

То је вероватно био допринос српског члана сценаристичког тима, Сарајлије Предрага Голубовића. Остали сценаристи били су: Павел Загребељни, Георги Лисенко и Александар Сацки. 
дукцији београдских предузећа Авала филма и Дунав филма, јула 1968; и последњи у тој серији Свейи йесак, у режији Мирослава Антића и продукцији Авала филма и Неопланте из Новог Сада, јула 1968. године. То је омогућено отопљавањем односа двеју држава и партија средином 1960-их година, али је тај тренд окончан већ 1968. године, интервенцијом Совјетског Савеза и других социјалистичких земаља у Чехословачкој. Период релативне слободе у култури Југославије, која је током 1960-их постепено освајана, завршен је новим таласом репресије, односно партијском акцијом сузбијања „црног таласа“ у кинематографији 1972. године (Petrović 1988; Tirnanić 2011). Наведени филмови су и у наредном периоду ретко кад јавно приказивани, али је својеврсни друштвени „табу“ на теме о Коминформу ипак био скинут, барем у српском културном простору.

После насилног прекида „црног таласа“ 1972. године, у југословенском филму је наступио период политички и идеолошки „коректних“ филмова, који нису дотицали осетљиве теме. У ратном жанру је доминирао филм који је артефицијелно, стилизовано и на модернизован начин представљао Други светски рат у Југославији. У тој врсти филма постојала је јасна подела на позитивне и негативне јунаке, која је била у складу са партијски верификованим догмама и тумачењима. Такви филмови су коришћени као забавно и васпитно средство, за разлику од „црног филма“, који је афирмисао стваралачке слободе и критичку дистанцу према прошлости и садашњости. Током 1960-их и 1970-их година, под утицајем америчких „каубојских филмова“, у Југославији се развила специфична естетика „партизанских вестерна“, која представља упадљиву разлику у односу на реалистички приступ у југословенском ратном филму током првих послератних година (Vučetić 2010: 130-151).

Почетком 1970-их година у југословенско-совјетској сарадњи снимљена су два ратна филма. Први, Сваgба 
(Свадьба), у режији Радомира Шарановића и у копродукцији киностудија „А.П.Довженко“ из Кијева и Филмског студија Титоград, довршен је 1973. године. Тема филма је грађански рат четника и партизана у Црној Гори 1943. године. Русија и Црвена армија се помињу узгред, као далека нада за помоћ при ослобођењу и узор успешне револуције. Помиње се и очекивање да јединице партизанског команданта Саве Ковачевића спрече енглеско искрцавање на Балкану. Четници су сарадници италијанских окупатора, али су их због њихових неуспеха Немци разоружали и повели на стрељање заједно са партизанима. Други филм је Единственная дорога (Оковани шофери), у режији Владимира Павловића и продукцији Мосфиљма и Филмског студија Титоград из 1975. године. ${ }^{8}$ Тај филм је „остао на нивоу неелаборираног крокија, интересантне идеје о окованим совјетским шоферима који возе немачки транспорт.“ (Kosanović, Tucaković 1998: 147). Радња се дешава априла 1944. године на простору нацистичке савезнице Независне Државе Хрватске - НДХ (виде се хрватске заставе и усташке пароле). Позитивни ликови су совјетски заробљеници и југословенски партизани, који нису национално декларисани, али говоре српском екавицом и зову се Љуба, Коста, Јавор, Срећко, Зоран, Бранка. Негативни су нацисти. Између њих је лик Гордане, избеглице из Београда9 ступа у љубавну везу са немачким официром, али у критичном тренутку убија команданта конвоја. Четника и усташа у филму нема. На крају партизани и ослобођени Руси одлазе да заједно ратују са Немцима. Драматургија филма је слаба, јер нема главног јунака, што није поправило ни учешће глумачке звезде Владимира Висоцког. У

в Премијера у СССР-у била је 1976. године.

9 Таквих избеглица није било. Управо обрнуто: Срби са простора НДХ су пред усташким терором бежали у Србију. 
филму има стилских елемената „вестерна“, али главни заплет се темељи на неспремности партизана да нападну конвој док се у њему налазе заробљени Руси. То чини идејно-политички континуитет са осталим српско-руским филмовима.

Неочекивано, у нову струју изразито стилизованих и идеолошки „коректних“ филмова о Другом светском рату у Југославији потпуно се уклапа Ogpeg 10 c Наварона (Force 10 from Navarone), настао у копродукцији Велике Британије и САД, а сниман на локацијама у Југославији. ${ }^{10}$ Тај британско-амерички филм је потпуно преузео вредносни клише и естетику југословенских ратних филмова који су се због ниских техничких стандарда, херметичних тема и језичке баријере знатно слабије продавали на Западу него у Источној Европи и Трећем свету. Ogpeg 10 c Наварона режирао је Гај Хамилтон (Guy Hamilton) ${ }^{11}$ 1978. године у продукцији Columbia Pictures \& Navarone Productions Ltd. Tај филм у потпуности понавља старе југословенске партијске тезе: 1) четници су сарадници Немаца и боре се против партизана и савезника; 2) вођа четника, по имену „Дражак“ (чиме се јасно алудира на Дражу Михаиловића) је монструм по карактеру и изгледу: игра га Ричард Кил (Richard Kiel), глумац који се специјализовао за негативце у филмовима о Џејмсу Бонду; 3 ) позитивни јунаци филма су југословенски партизани и амерички и британски командоси, а негативни ликови су Немци и четници. У односу на скромне стандарде југословенске продукције, тај филм је имао висок буџет од 10 милиона долара и укључивао филмске звезде Барбару Бах (Barbara Bach), Роберта Шоа (Robert Shaw), Харисона Форда (Harrison Ford) и Франка Нера (Franco

10 Филм су дистрибуирали Columbia-Warner Distributors (UK) и American International Pictures (US).

11 Хамилтон је режирао четири филма о тајном агенту Џејмсу Бонду у периоду 1964-1974. година. 
Nero). Тим филмом дошло се до потпуно супротних политичких порука од оних у америчким и британским филмовима о тој теми сниманих 1942/1943. године, као и до потпуног поклапања политичког и идеолошког садржаја англоамеричког комерцијалног и југословенског официјелног ратног филма. Режисер Хамилтон је очито гледао те филмове, јер је потпуно испунио стандарде жанра, али на вишем продукцијском нивоу.

Наредни период релативне слободе културног стваралаштва почео је после смрти Јосипа Броза Тита 1980. године и био је праћен економском и друштвеном кризом и попуштањем моћи Савеза комуниста. Први у том

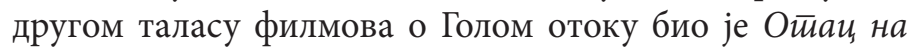

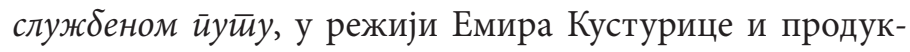
цији сарајевских кућа Сутјеска филма и Форума, довршен септембра 1985. године. Потом се марта 1986. године појавио филм Вечерна звона, у режији Лордана Зафрановића и продукцији Јадран филма из Загреба. Последњи који се бавио том темом био је филм Срећна Нова 1949, у режији Столета Попова, у продукцији Вардар филма из Скопља и Унион филма из Београда, довршен јуна 1986. године. Тиме су дефинитивно превазиђене све формалне и неформалне забране и отворено је проговорено о најтежем проблему совјетско-југословенских односа и то на простору целе Југославије. Тих година се и у штампи све више писало о том трауматичном периоду и његовим жртвама, а појављују се и прва историографска дела (Михаиловић и др. 2016 : 9-10). Ако се узме у обзир да су због Коминформа и русофилије Срби највише страдали (и ралативно и апсолутно посматрано) (Михаиловић и др. 2016: 38-40, 48), онда се тиме донекле објашњава чињеница да су први филмови који се баве Голим отоком настали у Србији. Друштво као целина је имало потребу да се суочи са том траумом, а уметници су проблем први артикулисали у друштвено прихватљивој форми. 
Целулоидни мост: две супротстављене интерпретације... 101

Ново виђење Другог светског рата у Југославији донео је филм Дивљи ветиар (Дикий ветер), у режији Валерија Жерегија и Александра Петковића, настао 1985. године у копродукцији београдског Филма данас, Молдова филма из Кишињева и Совинфилм из Москве. У јесен 1941. године двоје Руса, побеглих из немачког транспорта заробљеника, прукључују се партизанима у источној Србији. Рускиња је погинула, подсећајући гледаоца на пале црвеноармејце. Рус је био совјетски официр са искуством Шпанског рата, који је постао војни инструктор партизана. Иначе, Шпански рат је заиста био прилика за обуку комуниста за партизанско ратовање, а инструктори су им били совјетски официри (Тимофејев 2011: 193-204). Филм обнавља неке старе и доноси нове тезе о рату у Југославији: 1) повратак мотиву братства по оружју; 2) у филму нема идеолошки и политички спорних места између СССР и Југославије; 3) рат у Југославији приказан је као ослободилачки и грађански; 4) тема филма је искључиво српска и руска ствар - нема других југословенских нација; 5) позитивни јунаци су партизани - Срби и Руси, а негативни су Немци и српски квислинзи - недићевци и љотићевци. Четника у филму нема. Добијена битка прославља се само са српском заставом. Двоје црвеноармејаца играју истакнути совјетски глумци Светлана Тома и Виктор Проскурин, док главне негативне ликове играју американци Џеј Норт (Jay North) као немачки капетан Шофилд (Schofield); Дејл Камингс (Dale Cummings) као немачки поручник, Џорџ Монтгомери (George Montgomery) као љотићевски мајор Несторовић, Боб Свејн (Bob Swain) као немачки радиста, итд. Да је тај филм био снимљен 1969/1970. године, када је планирано, чинио би наставак низа филмова о руско-српским темама, али је та прилика пропуштена. Наиме, Живојин Павловић је први сценарио написао по мотивима прозе Всеволода Иванова, са намером да га Авала филм сними 
у сарадњи са руским продуцентом. Међутим, иако им се сценарио свидео, Руси се нису усудили да снимају по делу проскрибованог Иванова, па је Павловић прерадио текст, пренео радњу у српско поднебље и дао му наслов Вашар на свет̄ов Арханђела (Рајkić 2001: 284). Међутим, док је све то учињено, у Југославији је дошло до партијског обрачуна са „црним филмом“, а Павловић је био један од истакнутих аутора тог правца. Филм по његовом сценарију, а под новим насловом Дивљи ветиар, појавио се тек 15 година касније - али ипак на време да филмско тумачење Другог светског рата у Југославији и Србији доведе до његовог логичног исхода: изласка из идеолошке „бајке“.

\section{Закључак}

У периоду од 1941. до 1991. године у иностраним и копродукцијским филмовима посвећеним Другом светском рату у Југославији дошло је до идеолошког и политичког расцепа на два дискурса. Једну линију чине филмови рађени на Западу или у сарадњи југословенске кинематографије са западним продуцентима: Четиници! (1943), Прикривени (1943), Поэземна іерила (1944), Послеgни мост (1954), Долина мира (1956) и Ogpeg 10 c Наварона (1978). Први филм у том низу (Четинищи!) у изразито позитивном светлу представља српске четнике као патриоте и савезнике антихитлеровске коалиције, али се у наредним филмовима тај однос постепено мења - герилци су најпре изгубили идеолошке и националне ознаке (филмови Прикривени и Повземна іерила), а потом је тумачење прилагођено потреби уклапања Југославије у НАТО пакт (филмови Послеgюи мости и Долина мира). Југословенски партизани предвођени Комунистичком Партијом постепено заузимају улогу јединих позитивних јунака, који се понекад заједно с Американцима, а 
Целулоидни мост: две супротстављене интерпретације... 103

понекад са Норвежанима, боре против Осовине. На крају тог процеса реинтерпретације четници су недвосмислено представљени као негативни јунаци, сарадници нациста, злочинци и издајници (филм Ogpeg 10 c Наварона), дословно онако како је то било представљано у југословенској официјелној филмској продукцији и историографији.

Другу, паралелну линију, чине филмови настали у Совјетском Савезу или у сарадњи југословенских и

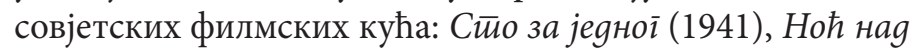
Беоірадом (1941), У йланинама Јуіоставије (1946), Алекса Дундић (1958), Проверено нема мина (1965) Оковани шофери (1975) и Дивљи ветиар (1985). Први филмови у том низу (Сйо за јеgноі и Ноћ наg Беоіраgом) јасно представља српске патриоте као борце против Осовине без икаквих идеолошких опредељења или ознака. Наредни филмови су трагали за сагласјем око заједничке прошлости, при чему су историјске чињенице понекад доспевале у сукоб са тренутним политичким потребама (нпр: У йланинама Јуїославије и Алекса Дунgић). Најзад, стигло се и до обострано прихватљивих виђења прошлости, у којима су и комунистичка идеологија и идеологија југословенства отишле у други план, а филм се приближио историјским фактима и вратио тумачењу по коме је најважније да су Срби и Руси заједно ратовали против истог непријатеља (филмови Проверено нема мина и Дивљь ветиар). Недуго после тог „филмског расплета“ нестали су комунистички режими и у Европи и у Југославији.

Преломни утицај на процес (ре)интерпретације прошлости био је сукоб око Коминформа који је у јавност избио 1948. године. Комунистичка партија Југославије најпре је наметнула официјелно виђење Другог светског рата у Југославији, а потом је ставила „табу“ на тему сукоба око Информбироа. Та два оријентира су одредила главни идеолошко-политички ток југословенске кинема- 
тографије 1941-1991. године. Проблем дубоке друштвене трауме до које је дошло услед сукоба око Коминформа на филму је покретан у два наврата: 1967-1968, када су се том темом бавили само српски аутори, и 1985-1986, када је она апсолвирана на простору целе Југославије. Сви проблеми уметничке обраде, политичке забране, скандали и полемике који су се јављали у вези овде анализираних филмова имали су узроке у идеологији и специфичној међународној позицији Југославије као социјалистичке земље укључене у западни систем безбедности. Та два елемента суштински су одредила интерпретацијски оквир у коме се кинематографија могла кретати. Када би тај оквир на неки начин био пробијен остајао је јасан траг у историјским изворима.

Филмови настали на Западу или у сарадњи западних и југословенских аутора полазили су од пропагандне потребе романтичног и, неретко, површног представљања историјске реалности у Југославији у складу са владајућом идеологијом и текућом политиком. Али, због промењених међународних околности и политичке потребе југословенског режима да се приближи НАТО пакту, ти филмови су временом прерасли у идеолошку „бајку“ о рату у Југославији, идентичну оној каква је негована у југословенском официјелном филму. С друге стране, руско-српски филмски дискурс почиње свој развој као идеолошка „бајка“ о херојском отпору окупатору и социјалној револуцији маса које предводи КПЈ. Међутим, услед постепене промене међународних околности, та струја је политички сазревала, све више се суочавајући са историјском реалношћу о Југославији и друштвеном потребом за напуштањем идеолошких илузија. 
Целулоидни мост: две супротстављене интерпретације... 105

Филмографија:

Антић, Мирослав. Свет̄и йесак. Авала филм и Неопланта, Југославија, 1968.

Афрић, Вјекослав. Славища. Авала филм, Југославија, 1947.

Bergstrøm, Kåre и Радош Новаковић. Крвави йуй / Blodveien. Норск-филм и Авала-филм, Норвешка и Југославија, 1955.

Ђорђевић, Младомир Пуриша. Поgне. Авала филм и Дунав филм, Југославија, 1968.

Жереги, Валерий Исаевич и Александар Петковић, Дивли ветар / Дикий ветер. Филм данас, Молдова филм и Совинфильм, СССР и Југославија, 1985/1986.

Зафрановић, Лордан. Вечерюа звона. Јадран филм, Југославија, 1986.

Катић, Милан. Тајна gворияа И. Б. Јадран филм, Југославија, $1951\left(20^{\prime}\right)$.

Käutner, Helmut. Послеgюи мости / Die letzte Brücke. Cosmopol film и УФУС, Аустрија и Југославија, 1954.

King, Louis. Chetniks! The fighting guerrillas, $20^{\text {th }}$ Century Fox, САД, 1943.

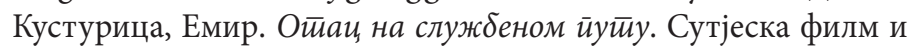
Форум, Југославија, 1985.

Лисенко, Юрий и Здравко Велимировић, Проверено нема мина / Проверено - мин нети. Киностудия „А.П.Довженко“ и Ловћен-филма, СССР и Југославија, 1965.

Луков, Леонид. Алекса Дунgић / Олеко Дунgич. Киностудия им. М. Горького и Авала-филм, СССР и Југославија, 1958.

Луков, Леонид. Ночь над Белградом, Боевой киносборник № 8. Ташкентская киностудия. СССР, 1941 (29').

Nolbandov, Sergei. Undercover. Ealing Studios, Велика Британија, 1943.

Nolbandov, Sergei. Underground guerrillas. Columbia Pictures, САД, 1944.

Павловић, Владимир. Единственная дорога/Оковани шофери. Мосфиљм и Филмски студио Титоград, 1975.

Павловић, Живојин. Буђене йацова. Филмска радна заједница, Југославија, 1967.

Попов, Столе. Срећна Нова 1949. Вардар филм и Унион филма, Југославија, 1986. 
Поповић, Никола. Мајка Кайина. Авала филм, Југославија, 1949. Раппапорт, Герберт. Сто за одного, Боевой киносборник № 2. Ленфильм, СССР, 1941 (18').

Роом, Абрам. В горах Югославии. Мосфиљм, СССР, 1946.

Hamilton, Guy. Force 10 from Navarone. Columbia Pictures \& Navarone Productions Ltd., Велика Британија и САД, 1978.

Шарановић, Радомир. Сваgба/Свадьба. Киностудия „А.П.Довженко“ и Филмски студио Титоград, СССР и Југославија, 1973/1974.

Штиглиц, Франце. Долина миру / Mr. Jim - American, Soldier, and Gentleman. Триглав филм, Југославија, 1956.

\section{Извори и литература:}

Belan, Branko. Sjaj i bijeda filma, Zagreb : Epoha, 1966.

Volk, Petar. Balada o trubi i maglama. Zagreb : Epoha, 1966.

Vučetić, Radina. „Kauboji u partizanskoj uniformi (Američki vesterni i partizanski vesterni u Jugoslaviji šezdesetih godina 20. veka)“. Tokovi istorije, Год. XVII, 6p. 2, (2010): 130-151.

Delibašić, Predrag. Gotovo zaboravljena istorija. Sećanja na rane dane jugoslovenskog filma. Beograd : Filmski centar Srbije, 2015.

Denić, Miomir. Moji filmski poslovi. Beograd : Institut za film, 1986.

Dick, Bernard F. The Star-Spangled Screen: The American World War II Film. Lexington 1996.

Jovićević, Mirko. Smrt je dolazila iz podzemlja. Gornji Milanovac : Privredna knjiga, [s. a.]

Kosanović, Dejan i Dinko Tucaković. Stranci u raju. Beograd : Stubovi kulture, 1998.

Милорадовић, Горан. Лейойа йоg наgзором. Совјеииски кулийурни уйииаји у ууіоставији 1945-1955. Београд : ИСИ, 2012.

Miloradović, Goran. „Trojanski konj imperijalizma’ preskače 'gvozdenu zavesu': Jugoslavija kao totalitarna država i njena uloga u hladnom ratu“. Tokovi istorije, Br. 1, (2011): 91-108.

Михаиловић, Драгослав, Мирослав Јовановић, Горан Милорадовић и Алексеј Тимофејев. Зайочениии Голої ойока. Реїисйар тица осуђиваних збої информбироа. Докуменит 
Целулоидни мост: две супротстављене интерпретације... 107

Уйраве яржавне безбеgносӣи ФНР Јуїославије. Београд : Архив Србије, 2016.

Obradović, Branislav, Radica Petrović i Ljubica Milenković-Tatić. Filmografija jugoslovenskog igranog filma 1945-1980, Beograd : Institut za film / Časopis Filmograf, 1981.

Ostojić, Stevo. Rat, revolucija, ekran. Zagreb : Spektar, 1977.

Pajkić, Nebojša. Jahač na lokomotivi. Razgovori sa Živojinom Pavlovićem. Beograd : SKC, 2001.

Petrović, Aleksandar. Novi film II (1965-1970) „Crni film“. Beograd : Naučna knjiga, 1988.

Raspor, Vicko. Riječ o filmu. Beograd : Institut za film, 1988.

Ристовић, Милан. „Мајка Катина међу Маркосовим партизанима или филм који није постојао“. Гоgишғьк за gрушимвену истиорију, Год. XVII, бр. 2, (2010): 7-21.

Savich, Carl. British Wartime Film: On the Set of the Movie Chetnik in 1942. http://serbianna.com/blogs/savich/archives/2608. Веб. 20. 04. 2017a.

Savich, Carl. Chetniks! The Fighting Guerrillas (1943) - A Critical Reappraisal in 2008. http://www.generalmihailovich. com/2008/03/chetniks-fighting-guerrillas-1943.html. Веб. 20. 04. $2017 \mathrm{~b}$.

Адибеков, Г. М. и др. Совещания Коминформа, 1947, 1948, 1949. Докуменйы и матиеријалы, Москва : РОССПЭН, 1998.

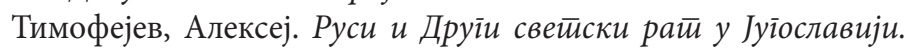
Уйииај СССР-а и Руских емиіранайа на gоїађаје у Jуі̄ославији 1941-1945. Београд : ИНИС, 2011.

Tirnanić, Bogdan. Crni talas. Beograd : Filmski centar Srbije, 2011. Tomasevich, Jozo. The Chetniks. Warand Revolution in Yugoslavia 1941-1945. Stanford: Stanford University Press, 1975.

„How Yugoslavia Fights Back“. The British Picture Post, October 10.1942, Vol. 17, No. 2. 17-19.

Čolić, Milutin. Jugoslovenski ratni film I-II. Beograd : Institut za film/Titovo Užice : Vesti, 1984.

Škrabalo, Ivo. 101 godina filma u Hrvatskoj 1896.-1997:Pregled povijesti hrvatske kinematografije. Zagreb : NZ Globus, 1998. 


\title{
Goran Miloradović
}

\author{
CELLULOID BRIDGE: \\ TWO OPPOSING INTERPRETATIONS OF THE \\ SECOND WORLD WAR IN YUGOSLAV FEATURE FILM \\ (1941-1991)
}

\section{Summary}

Socialist Yugoslavia (1945-1991) was in a specific position between the two geopolitical military and political blocks: NATO and Warsaw Pact. It was forced to float and sometimes to choose sides, seeking its international position and role. Such a situation influenced its cultural production, especially film. This article is based on the assumption that the analysis of the ideological and political content in the Yugoslav war feature film could lead to certain conclusions about the foreign policy of this country. Twenty four feature films were analyzed. Presentation of the current, politically and ideologically important themes in cinematography, primarily the interpretation of the Second World War in Yugoslavia, allows the film to be used as a historical source for political and social issues. Reliability of the information collected in this way is very high, because the film was carefully controlled by the party-state, while themes and financial resources often came from the sphere of politics. If a film which opposes the Yugoslav policy of Yugoslavia would appear, it would have been removed from the public, and the authors would have been sanctioned. Such events gave valuable data for historical analysis. An important indicator of the international political relations were film co-productions, so special attention was paid to their perception in political circles. Finally, the political scandals that have sometimes occurred around some films provided another very important group of data. The position of Yugoslavia between two military and political blocks led to the emergence of two parallel and different interpretations of World War II in Yugoslavia both in Yugoslav and in foreign war feature film. One interpretation affirms the multinational Yugoslav statehood and 
Целулоидни мост: две супротстављене интерпретације... 109

its ties with the West, even at the cost of preserving Communist power in it. The other one highlights Serbian-Russian historical ties and traditional values, systematically undermining the official Yugoslav interpretations of recent history and gradually releasing ideological illusion. 